Shivaji University, Kolhapur

Shri G.S. Institute of Science \& Technology, Indore

Snow \& Avalanche Studies Establishment, C/o 56 APO

Space Applications Centre, Ahmedabad

Speck Systems Pvt. Ltd., Hyderabad.

State Council for Science, Technology \& Environment, Shimla

State Forest Research Institute, Jabalpur

State Remote Sensing Applications Centre, Rajasthan, Jodhpur

Tamil Nadu Agricultural University, Coimbatore

Town \& Country Planning, Madras

University of Kerala. Trivandrum

University of Roorkee, Roorkee

U.S. Embassy, New Delhi

Wadia Institute of Himalayan Geology, Dehra Dun

Water and Land Management Institute, Aurangabad

\title{
CORRECTION
}

\section{(CHAPTERS NEWS)}

In the Journal of Indian Society of Remote Sensing (Vol. 18, No. 4, Dec. 1990 issue) it was inadvertently mentioned in the Ahmedabad Chapter News that "SAC Courier" is brought out by the Ahmedabad Chapter of ISRS. In fact, the newsletter "SAC Courier" is an official publication of the Space Applications Centre, Ahmedabad. The error is regretted. 